\title{
A Contrastive Morphological Analysis of Tense Formation in Igbo and Yoruba: Implication on Learners and Teachers
}

\author{
Aghaegbuna Haroldson Uwaezuoke \& Olufunmilayo M. Ogunkeye \\ http://dx.doi./org/10.4314/ujah.v18i3.10
}

\section{Abstract}

This paper is a contrastive morphological study of tenses in the Igbo and Yoruba languages. It is limited to tenses only excluding aspects. It intends to aid speakers of the two languages in their effort to learn another's language. This is considered vital since the two languages are among the major languages in Nigeria and people have become interested in learning them. Globalization has also necessitated the transfer of technological information into these languages, thus making this paper an invaluable one. Data for the two languages are collected from the primary and secondary sources in addition to the researchers' intuitive knowledge of the languages. Data are analyzed using a contrastive analysis approach. Our findings show that there are differences in the processes of forming tenses in both languages. For instance, Igbo has indicative suffix $-r V$ which may be deleted or optionally used with certain verbs in the present, and obligatorily used for verbs in the past, but in Yoruba, the present tense and past tense are unmarked. A hyphen is written between the future morpheme and the verb in Igbo, but Yoruba has a separate free morpheme to express the future. Also, in Igbo the $1^{\text {st }}$ person singular pronoun and the $3^{\text {rd }}$ person plural pronoun can come after the future morpheme -ga which is prefixed with a followed by the prefixed verbroot, but in Yoruba all the subject pronouns come before the future morpheme. These areas of differences are predicted by contrastive analysis as constituting learning difficulties. This paper 
proffers solution to the perceived tense problem by advocating that teachers should be more attentive to their students' speeches and write-ups in order to immediately correct any error that might occur. They should avail themselves of the available materials on contrastive analysis such as this and guide the students to know the formation of tenses in these languages and immediately correct any error that might occur or better prevent the errors from manifesting.

\section{Introduction}

Nigeria is a multilingual country with over 500 languages. Over the years efforts have been made by government to solve Nigeria's language problem. One of such efforts is the National Policy on Education, which has encouraged the use of the mother tongue as the language of instruction at the primary school level. Nigerians are also encouraged to learn one of the three major Nigerian languages - Igbo, Hausa and Yoruba. With this, speakers of these major languages as well as speakers of other languages are expected to show keen interest in learning one another's language.

In the Nigerian educational system, the Igbo and Yoruba languages constitute at least a school subject; especially in the different regions where they are spoken. Learning of a second language has not always been easy due to differences that exist between L1 and L2. Differences in languages can occur at different levels of grammar as noted by Anagbogu, Mbah and Eme (2001) such as phonetics, phonology, morphology, syntax and semantics. This paper is a contrastive morphological study of tenses in Igbo and Yoruba. These two languages belong to the kwa language family following Greenberg's (1963) language classification. They are among the three major languages in Nigeria with the Hausa 
language, which have resulted in the use of the acronym WAZOBIA. Igbo is spoken in the Eastern part of Nigeria, while Yoruba is spoken in the Western part. There are however perceived differences in the two languages, one of which is tense formation. Although, as noted by Saeed (2003), tense and aspect interact in subtle ways and are marked on verb in similar ways, discussions of this paper are limited to only the tense - present, past and future, since addition of aspect will make the paper very voluminous. This work is carried out within the framework of contrastive analysis.

It has been established that differences in two languages usually constitute learning problem for L1 speakers learning L2. Okorji and Okeke (2009), for example, show that differences in the phonemes of two languages or dialects often constitute learning problem for the speakers of the languages/dialects as they try to learn another. Likewise, differences in the tenses of two languages can also constitute learning problem for speakers of the languages trying to learn another. This suggests the importance of this study. This paper will, therefore, be relevant to the Igbo and Yoruba students learning the other's language as well as their teachers as it presents a contrastive analysis of tense formation in the Igbo and Yoruba languages as well as provides solution on how to overcome the problems the students and their teachers might encounter. It will enable the students to gain competence in the languages as well as help them not only to pass their Igbo and Yoruba subjects, but also to be able to communicate freely with speakers of the languages.

As the world has become a global village, with its attendant need for exchange of information and technological transfer, it has become necessary for people to be conversant with grammar of different languages. This paper will not only be beneficial to 
speakers of other Nigerian languages, but also to foreigners who may be interested in learning the Igbo or Yoruba language. Translation experts who may have the need to translate vital information from other languages into Igbo or Yoruba language for the benefit of the Igbo and Yoruba people will also find this material very interesting as it will enable them to be conversant with the workings of the two languages.

Our instrument for collection of data was mainly partially structured interview. Four consultants were chosen with equal male/female representation - two Igbo speakers and two Yoruba speakers. They are people between forty and eighty years. Each of the researchers is a native speaker of one of the languages. Their intuitive knowledge of the languages, therefore, helped a lot.For tone marking of the Igbo data, the researchers have adopted the Green and Igwe (1963) tone marking convention of leaving high tone unmarked in Igbo and low tone marked with grave accent [ ]; in line with IPA, we have marked downstep tone with acute accent on the tone bearing unit and down pointing arrow before the syllable that bears the tone [ ${ }^{\downarrow}$ ]. For Yoruba data, we adopt the convention of marking high tone with acute accent [ ' ], low tone marked with grave accent [ $\left.{ }^{`}\right]$ and mid tone left unmarked.

\section{Overview of Contrastive Analysis}

Contrastive analysis has always been relevant to language teachers and language learners for effective teaching and learning of languages respectively. Past studies on contrastive analysis of languages point to the relevance of contrastive studies to the language teacher and language learner in the effective teaching and learning of languages respectively. As noted by Dipietro (1971), cited in Hartmann (1980: 22), contrastive study is motivated mainly by the foreign language teacher having a need to uncover 
important areas of differences between the target language and that of his students. This suggests that contrastive analysis is a teaching strategy used to predict and overcome errors of differences in the course of teaching a language.

The implication of differences in two languages, according to Lado (1957) cited in Corder (1973: 29)is that "the student who comes in contact with a foreign language will find some features of it quite easy and others extremely difficult. Those elements that are similar to his native language will be simple and those elements that are different will be difficult." This view has been supported by many authors in their separate investigations, including Mensah and Ojukwu (2003), Eme and Odinye (2008) who also note that differences in aspects of the target language and the students' L1 will very likely result in mother tongue interference, especially if there is no contrastive analysis the teacher could rely on in preventing interference errors from manifesting.

\section{Some Previous Works on Contrastive Analysis}

In a contrastive analysis of the phonology of English and Spanish, James (1983) observes the possibility of two languages having corresponding phonemes with similar allophones. He states that the English and Spanish languages have the phonemes $/ \mathrm{n} /$ and $/ \mathrm{y} /$, but while $/ \mathrm{n} /$ occurs before vowels, dental or alveolar consonants as well as at word final position in both languages, / $\mathrm{y} /$ occurs in different environments in the two languages. In English, he says

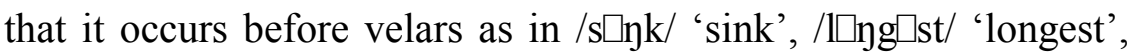
but in Spanish, it occurs before $/ \mathrm{h} /$ and $/ \mathrm{w} /$ as in /estrayhero/ (Estranjero) 'foreigner' and /un' we $\beta \mathrm{o} /$ (Un huveno) 'an egg'. In his view, the teacher and the learners should be familiar with the environments of occurrence of the two sounds in the two languages so as to avert pronunciation errors. The scholar also contrasts the 
phonology of English and French and observes that the phoneme $/ 3$ / exists in both languages; but in English, it occurs only in medial and final positions while in French, it occurs in initial, medial and final positions. He concludes that the English learner of French would consequently have difficulty in pronouncing $/ 3 /$ at the initial position of words.

In their contrastive analysis of English and Igbo phonemes, Anagbogu and Eme (2000) observe that there are many vocalic phonemes of English which do not exist in Igbo. This situation to them will make an Igbo adolescent learning the English language to readily find substitutes from his L1 phoneme inventory in his pronunciation of the English words that contain unfamiliar vowels. It will also make him to have different pronunciation from that of a native speaker of English. Some of their data which show differences between the Received Pronunciation English (RPE) speaker and an adolescent that has the Igbo language as his L1 are as follows:

1. i. $/ \mathfrak{a} / \rightarrow / \mathrm{a} /$

\begin{tabular}{|c|c|c|}
\hline $\begin{array}{l}\text { Words } \\
\text { man } \\
\text { cat }\end{array}$ & $\begin{array}{l}\text { RPE } \\
\text { /mæn/ } \\
\text { /kæt/ }\end{array}$ & $\begin{array}{l}\text { Igbo } \\
/ \mathrm{man} / \\
/ \mathrm{kat} /\end{array}$ \\
\hline \multicolumn{3}{|c|}{$/ \mathrm{a} / \rightarrow|\mathrm{a} /, / 3 / \rightarrow| \mathrm{a} /, / 3 / \rightarrow / \mathrm{e} /, / \square / \rightarrow \mid \square /$} \\
\hline $\begin{array}{l}\text { Words } \\
\text { perverse }\end{array}$ & $\begin{array}{l}\text { RPE } \\
\text { / pəv3s / }\end{array}$ & $\begin{array}{l}\text { Igbo } \\
\text { /pavas/ }\end{array}$ \\
\hline bird & /b3d/ & /bed/ \\
\hline love & $/ \square \mathrm{v} /$ & $/ 1 \square \mathrm{v} /$ \\
\hline
\end{tabular}

Eme and Odinye (2008) state that the absence of the Igbo phonemes / $\square \square \square \mathrm{j} \mathrm{jw} \mathrm{j} \mathrm{w} \mathrm{kp} \mathrm{gb} \mathrm{kw} \mathrm{gw/} \mathrm{in} \mathrm{Chinese} \mathrm{would}$ constitute pronunciation problem for Chinese speakers learning the 
Igbo language, while the absence of the Chinese aspirated segments $/ \mathrm{p}^{\mathrm{h}} \mathrm{t}^{\mathrm{h}} \mathrm{k}^{\mathrm{h}} \mathrm{ts}^{\mathrm{h}} \square^{\mathrm{h}} \mathrm{t} \square^{\mathrm{h}} /$ and retroflex segments $/ \square \mathrm{t} \square \mathrm{t} \square^{\mathrm{h}}$ $\square /$ in Igbo would constitute pronunciation problem for Igbo speakers learning the Chinese language.

Eme and Uwaezuoke (2015) in their study, Phonology of Umùòlum Igbo and Standard Igbo: Implications for Teaching and Learning of Standard Igbo in Umùolum point out that although it may not always be the case that interference errors will occur in the speech of L2 or FL learners, it is usually the case. They submit that with contrastive analysis, errors could be predicted and efforts made to prevent them from manifesting or readily correct them when they appear in the speech of language learners. They say that the teacher can achieve this through his design and use of effective teaching and testing materials, with emphasis on areas likely to pose problems or already posing problems to the language learners.

In a contrastive study of English and Igbo prepositions, Nwankwo (2009) discovers that English has many prepositions unlike Igbo, which enables it to differentiate between prepositions that the Igbo language lumps together as same. She observes many differences in English and Igbo prepositions and notes that it implies that both the teacher and learner should anticipate some difficulties and so teach/learn prepositions in context. This, she points out is in addition to the teacher paying attention to the collocation in structure of the preposition, especially where it is used idiomatically.

\section{The Notion of Tense}

Tense to Lyons (1968) is a deictic category which morphologically depends wholly or partly on deixis. This view is supported by many scholars including Comrie (1985) and Saeed (2003). Comrie 
(1985) considers tense as a grammatical expression of the time of situation described in the proposition relative to some other which may be the moment of speech (present tense) or some reference time which signals to a time prior to another time in the past (past tense) or what will happen (future tense). It is this issue of time relation with tense that makes Palmer (1974) to simply regard tense as a linguistic reference to time. Also agreeing with the issue of time relation, Emenanjo (2015:460) defines tense as "the grammaticalization of the location of time in trinary terms of past, present and future".

One can hardly discuss tense without talking about verb. This is because verb is very important category onto which some other categories like tense are marked. Bhat (1999:13) considers tense to be 'an inflectional marker of the verb used for denoting the temporal location of an event (or situation)', while Aronoff (2011) notes that it is the only category that is marked directly on the verb and also directly connected to time. That is why Eyisi (2004) succinctly considers tense as referring to any of the forms of a verb that may be used to indicate the time of the action or state expressed by the verb. Before proceeding, we shall discuss the structures of verbs in the two languages.

\section{The structure of Igbo verbs}

Igbo has two types of verb formation - simple monosyllabic verb and compound verbs. The simple monosyllabic verbs are verb roots consisting of a consonant followed by a vowel and they have a CV syllable structure. The verbroot is a very important part of verbs in Igbo. Okonkwo (1974) describes it as 'permanent stump' or the nucleus upon which prefixes and suffixes are attached in order to get different forms of the verb. 
Monosyllabic verbs have either a low tone or a high tone in Igbo.

\section{High tone}

ga 'go'

de 'write'

nye 'give'
Low tone

dà 'fall'

zà 'seep'

nyà 'ride'

To form infinitives in Igbo, the vowel $\mathrm{i} / \mathrm{i}$ are prefixed to the verb root based on the Igbo vowel harmony rule.

$$
\begin{array}{ll}
\text { ịgā 'go' } & \text { ịdà 'fall' } \\
\text { idēe 'write' } & \text { ịzà 'sweep' } \\
\text { inyēe 'give' } & \text { ịnyà 'ride' }
\end{array}
$$

Compound verbs in Igbo are made up of two, three or more syllables. Okonkwo (1974) discloses that any verb with more than two syllables is derived through a process called progressive expansion. In compound verbs of two syllables, a verbroot is suffixed to another verbroot. One or two elements can be suffixed to the verb root to get a compound verb.

2. bù we

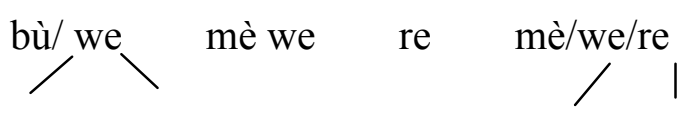
carry begin to root suffix do begin to for root suffix suffix 'begin to carry' 'begin to do for'

Compound verbs in Igbo can also be formed through serial verb construction (Afigbo, 1981). There is a verb and nominal elements which, according to Emenanjo (1978), are two - CP and BCN. While Emenanjo (1978) regards $\mathrm{CP}$ as complement and $\mathrm{BCN}$ as 
Bound Cognate Noun, Green and Igwe (1963) earlier refers to $\mathrm{BCN}$ as cognate object. In the underlying structure, verbs co-exist with both $\mathrm{CP}$ and $\mathrm{BCN}$ but in the surface structure, either one or both are used.

Some verbs do not make full meaning when they standalone except when they are used with their complements, that is, they have $\mathrm{V}+\mathrm{CP}$ formation.

3. Ifeanyì nà- abụ̀ abụ

Ifeanyi Progr. $\mathrm{BCN}+$ Root $\mathrm{CP}$

'Ifeanyi is singing a song'

In this sentence, the meaning of nà-abù would not have been complete without the complement abù. The $\mathrm{BCN}$ is derived from the verbroot by prefixing $a$ or $e$ based on the Igbo vowel harmony rule as in $O$ nà-abù abù 'It is singing that he is singing'.

The serial verb construction links two or more independent constructions of the same type and each of the verbs used adds a meaning to the construction. It is also used to express prepositions. 4.

O gàrà ahịa zụta anụ

PRON. Verbroot $+\mathrm{rV}($ PAST)market buy + suf. meat

's/he went to the market and bought meat'

O jì azụ si ofē

PRON Verb(PAST) fish cook soup

's/he cooked the soup with fish'

Not all the verbs have an object in serial verb construction and an object can occur with the last verb as can be seen below:

5. O bịàrà kiri mìga

PRON come $+\mathrm{rV}(\mathrm{PAST})$ watch(PAST)wrestling

's/he came and washed wrestling' 


\section{The structure of Yoruba verbs}

Yoruba like Igbo has two types of verbs - simple monosyllabic verbs and compound verbs. Simple monosyllabic verbs have only one syllable consisting of a consonant followed by a vowel.

6.

$$
\begin{array}{ll}
\text { wá 'come', lọ 'go' } & \text { sùn 'sleep' } \\
\text { jẹ 'eat' } & \text { kọ 'write' }
\end{array}
$$

\begin{tabular}{|c|c|c|}
\hline $\begin{array}{l}\text { verb }+ \text { noun } \\
\text { ran }+ \text { eti } \\
\text { sew }+ \text { ear }\end{array}$ & $\begin{array}{l}\text { Verb } \\
\text { rántí }\end{array}$ & $\begin{array}{c}\text { Gloss } \\
\text { 'remember' }\end{array}$ \\
\hline $\begin{array}{l}\text { kán }+ \text { ojú } \\
\text { drop }+ \text { eye }\end{array}$ & kánjú & 'hurry' \\
\hline $\begin{array}{l}\text { rö } \\
\text { gush }\end{array}$ & röju & 'endure' \\
\hline $\begin{array}{l}\text { ro }+ \text { ojú } \\
\text { ache eye }\end{array}$ & rojú & 'procrastinate' \\
\hline $\begin{array}{c}\text { tì } \\
\text { push }\end{array}$ & tijú & 'be bashful' \\
\hline
\end{tabular}

Compound verbs in Yoruba have two or more syllables. It can take the following formations:

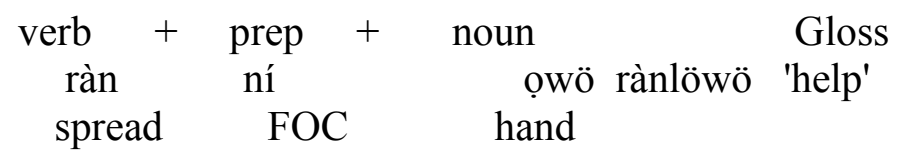

$\begin{array}{lllll}\text { rán } & \text { ní } & \text { etí } & \text { ránlétí } & \text { 'remind' } \\ \text { send } & \text { FOC } & \text { ear } & & \end{array}$

(Ogunkẹyẹ 2004)

Verb + Verb, including serial verbs 
Ogunkẹẹ (2003) identifies four types of serial verb constructions:

8. i. The instrumental SVC

Bàbá fi kòkò se ọbê

Father use pot cook soup 'Father cooked the soup in a pot'

Adé fi õbẹ gé i $\square$ u

Adé use knife cut yam 'Adé cut the yam with a knife'

ii. The resultative SVC

Bölá $f a$ okùn le

Bölá pull rope (be)tight 'Bölá tightened the rope'

Tolú fọ $\quad \mathrm{a} \square \mathbf{q} \quad \boldsymbol{m} \ddot{\boldsymbol{o}}$

Tolú wash clothes (be)clean 'Tolú washed the clothes clean'

iii. The Direct Object - Argument Sharing SVC

Iyá $\square \ddot{\text { ë igi tà }}$

Mother break wood sell 'Mother broke wood to sell

(or and sold it)'

Olú ra $\quad$ i $\square$ u je

Olú buy yam eat 'Olú bought yam and ate it'

iv. The splitting SVC.

gbà gbö

receive hear

'believe'

Adé gba Jídé $\boldsymbol{g} \boldsymbol{b} \ddot{\boldsymbol{o}}$

'Adé believes Jídé'

Jídé ni Adé gbàgbö.

'It is Jídé that Adé believes`

Jídé FOC Adé believe 
bà jë

touch answer

'spoil'

Adé bà ọkõ jë

'Adé spoilt the car'

Ọkõ ti Adé bàjë...

'The car that Adé spoilt'

car that Adé spoil

The $\mathrm{V}+$ Noun formation consists of a verb and a nominal element. In some cases, they are separated in a sentence and in some cases they are not.

From examples (7), the verb and nominal elements are sometimes split and sometimes not split. The reason, according to Ogunbowale (1970), is that the noun parts are in some cases not clear and in some cases they are clear, the verbs cannot be given literary meaning to avoid alteration in the meaning of the compound verb. According to Ogunkeye (2004), parts of a derived word, are referentially opaque, that is, it is impossible to refer to their parts. For example, in a compound such as bínú (bí-inú ( deliver stomach 'be angry'), inú (stomach) does not serve to pick out any specific object. In the same way, the nouns in V-N compounds are referentially opaque and the compounds can therefore only be idiomatic expressions.. If the noun is referential, the construction is most probably a phrase with a literal meaning. For verb + verb formation, there are two verbs, which in a sentence may be split. The verbs, whether they are split or not, share an object and one tense value, i.e tense is marked only on the first verb.

The serial verb construction is used to link two or more independent verb phrases. The first verb in the construction is primary while others are secondary or modifiers.

9. O mú ìwé náà lo 
'he took the book away'

This example above could be rendered as;

10. Ó mú ìwé náà ó (si) lọ

He took the book (and) he went'

Also; Bunmi bá Fémi lo

'Bunmi joined/ helped Femi to go'

From the foregoing, both languages virtually operate the same system of verb formation with each having both simple and compound verb constructions. Their only difference is that Yoruba has compound verb formation consisting of verb + preposition + noun, while it does not exist in Igbo. Secondly, there is no prefixation for the formation of infinitives in Yoruba unlike in Igbo where infinitives are formed by prefixation of the vowel infinitive $\mathrm{i} / \mathrm{i}$ to the verbroot based on the Igbo vowel harmony rule.

\section{Tense formation in the Igbo and Yoruba languages}

Emenanjo (1978) discloses that in African languages, duration is mostly emphasized rather than the actual time. To buttress this point, Emenanjo (2015) maintains that even though tense might be a universal phenomenon, its three demarcations in terms of past, present and future do not exist in all languages. This suggests that tense is not explicit in all languages and that one may need to also discuss duration (aspect) while discussing tense. The fact still remains that the two languages have their ways of expressing time - present, past or future. This is in agreement with the view of Omamor (1982) that all languages have ways of expressing the three points in time and so for that reason all languages have present, past and future tense and all people have the same concept of time and order, but only differ in not having the same surface 
representation of tense. However, the main focus of this study is on tense only.

\subsection{Present and Past in Igbo and Yoruba}

Early studies on tense in Igbo hold the view that tense in the language include present, past and future (See Okonkwo, 1974; Oluikpe, 1978; and Emenanjo, 1978). Emenanjo (1978), for example, discloses that for present tense, the indicative morpheme $-\mathrm{rV}$ is sometimes deleted for some verbs and optionally used for others, but for past tense, it is obligatorily used.

Modern studies on tense in Igbo suggest that present tense does not exist in the language. Enemor and Osinomumu (2005) submit that tense in Igbo shows the time of an action/event through the inflection of the verbroot. They identify three types of tenses in Igbo excluding the present tense, namely; tensi ndinaazu 'past tense', tensị ngaradi 'unfulfilled tense' and tensị ndiniihu 'future tense'. Emenanjo (2015) seems to agree with this view where he points out that the three-way tense distinction in terms of present, past and future does not seem to hold in Igbo (p.450). He also points out that Igbo does not have present tense. He, however, differs from Enemor and Osinomumu (2005) in the sense that in place of tensi ngaradi 'unfulfilled tense', he identifies past in the future tense.

The argument against the existence of present tense in Igbo may be valid if on grounds of no clear-cut distinction observed by Emenanjo (1978) between the way present time and past time are expressed in the language, which is reemphasized by Uwalaka (1988) where she submits that Igbo does not have one particular verb form for expressing present meaning. In the opinion of Emenanjo (2015:450), past tense is 'the one absolute tense that is clearly marked in (all dialects of) Igbo'. 
In Igbo sentences, the first person singular subject pronoun and the third person plural subject pronoun are sometimes written before the verb and sometimes after the verb or after the auxiliary elements. Other subject pronouns appear before the verb.
11. a. Emeka jọ̀(rọ̀) njọ
b. Ùle à tà(rà) akpụ̀ Emeka be(rV) ugly
'Emeka is ugly'
exam this be(rV) difficult
'This exam is difficult'

Emenanjo (1978:171) uses the term 'indicative' for this kind of construction which means that the verb form indicates the salient fact about the verb used without regard to time. To Welmers and Welmers (1968), the use of 'indicative' for action verbs denotes past tense, but Ward (1935) points out that if it is used for descriptive verbs, it denotes present tense. One very important fact is that one can never rule out context in knowing the actual time in Igbo.

Obiamalu (2015), pointing out that factativity and tense are marked in Igbo by only one rV suffix in most dialects of Igbo, opines that the interpretation of verb as either present or past is dependent on the semantic features of the verb. Continuing, he says that if the verb is [+eventive], the $\mathrm{rV}$ suffix is given a past tense reading, but if the verb has the feature [-eventive], then the rV suffix does not takes a past tense reading as shown below:

12a. Òbi gbùrù agwọ

Obi kill-FACT.PAST snake 'Obi killed a snake'

Past tense reading

b. Àda nwèrèegō Ada own-FACT money

Non past tense reading 
'Ada has money'

(Adapted from Obiamalu, 2015:69)

Citing Emenanjo (1985:176), Obiamalu (2015) also notes that some verbs in Igbo could appear bare while some allow the rV suffix and still maintain a present reading.

Bare form:

$13 \mathrm{a}$

Àmaka wụ̀ nwokē

Amaka be man

'Amaka is a man'

With rV suffix:

b.

Àda mà-rà

mmā

Ada be.beautiful-FACT beauty

'Ada is beautiful'

Obiamalu observes that most eventive verbs will express present meaning using na auxiliary duration aspect marker, which could be given either a habitual reading or a progressive reading in most dialects.

14. Òbi nà è- ri edè

Obi DUR e-eat cocoyam

'Obi eats cocoyam'

(Habitual reading)

'Obi is eating cocoyam' (Progressive reading)

(Adapted from Obiamalu, 2015:77)

In Yoruba, the difference between present and past tense is tenuous because both are formed the same way. The subject pronouns always come before the verb. Odunuga (1982) discloses that the present tense and past tense are unmarked in Yoruba. Ogunbowale (1970) has earlier pointed out that actions in the present or in the 
past are known by the complete absence of the formants for the formation of a future tense. Also, context helps to know the exact time of an action.

15. Mo lo si ile iwe

'I go to school/ I went to school'

Table 1 Present tense

\begin{tabular}{|c|c|c|}
\hline Igbo & Yorùbá & Gloss \\
\hline a.M gà(rà) akwụkwọ & Mo $\boldsymbol{l o g} /$ Mo nlo si ilé-ìwé & \\
\hline I go(rV) school & I go/ I go to school & I go to school \\
\hline b. Ojo jọ̀(rọ̀) njọ & Ojó burëwà & \\
\hline Ojo be(rV) ugly & Ojó be.ugly & Ojó is ugly \\
\hline c. Ủle à tà(rà) akpụ & Idánwò yi le & \\
\hline exam this be(rV) difficult & exam this be hard & $\begin{array}{l}\text { This exam is } \\
\text { difficult }\end{array}$ \\
\hline
\end{tabular}

Table 2 - Past tense

\begin{tabular}{|c|c|c|}
\hline Igbo & Yorùbá & Gloss \\
\hline $\begin{array}{l}\text { a.M gàrà akwụkwọ } \\
\text { I go+rVPAST school }\end{array}$ & $\begin{array}{l}\text { Mo lo si ilé-ìwé } \\
\text { I go to house-book } \\
\text { Ojó burëwà }\end{array}$ & $\begin{array}{l}\text { I went to } \\
\text { school }\end{array}$ \\
\hline $\begin{array}{l}\text { b.Ojo jọ̀rọ̀ njọ } \\
\text { Ojo be+rV PAST ugly }\end{array}$ & $\begin{array}{l}\text { Ojó be.ugly } \\
\text { Idánwò náà le }\end{array}$ & Ojó was ugly \\
\hline $\begin{array}{l}\text { c. Ùle ahụ̀ tàrà akpù̀ } \\
\text { exam that be+rV PAST difficult }\end{array}$ & exam the be hard & $\begin{array}{l}\text { The exam } \\
\text { was difficult }\end{array}$ \\
\hline
\end{tabular}

As seen in tables 1 and 2 above, the forms of verbs in Yoruba do not change when they are used in the present and the past. The 
context will determine the interpretation as either present or past. For example, it is easy to interpret Idánwò yi le (This exam is difficult) in the present tense because of the presence of yil (this) and Idánwò náà le (The exam was difficult) as past because of the presence of náà (the/that). It would appear that the default mode of interpreting action verbs is the past, whereas in the present, they tend to appear with the aspectual marker $\boldsymbol{p}$ (see example above)

16. Mo gbe ni ilé Ojó

I lived in Ojó's house./ ? I live in Ojó's house.

Mo $p$ gbé ní ilé Ojó.

I cont. live in Ojó's house.

Ojoojúmö ni ßade $\mathrm{p}$ jó

Everyday FOC ßade cont. dance ' Bade dances everyday'

Ojoojúmö ni ßade jó

Everyday FOC ßade dance 'ßade danced/*dances everyday'

But stative verbs appear not to take the aspectual marker to indicate the present tense.

17. Adé fẹràn iyán

Adé likes/liked pounded yam.

*Adé $p$ fẹràn iyán 'Adé likes pounded yam'

Also, in Igbo, it is easy to interprete present with the presence of demonstrative $a$ marked with a low tone, meaning 'this' and past with demonstrative $a h u$ or by doubling the demonstrative $a a$ marked with high-low tones, both meaning 'that' e.g ùle à tàrà akpụ 'this exam is difficult'; ùle ahụ tàrà akpụ 'that exam was 
Agà hà àta/Agà hà ịtā 'They will chew'

In Yoruba, two morphemes are used to express future tense and they are yí and máa (á). They are referred to as preverbal auxiliaries.

21 a. Mo máa lọ 'I shall go'

O máa lọ 'You will go'

Ó máa lọ 'S/he will go'

A máa lọ 'We shall go'

È máa lọ 'You will go'

Wọn máa lọ 'They will go' b. Emi yíò kọ 'I shall write' Iwọ yío kọ 'You will write' Oun yíò kọ 'S/he will write' Àwa yíò kọ 'We shall write' Ėnyin yíò kọ 'You will write' Awọn yíò kọ 'They will write'

Table 3 - Future tense

\begin{tabular}{|c|c|c|}
\hline Igbo & Yorùbá & Gloss \\
\hline a. M gà-àga/ Agà m̀ àga & Mo máa lọ & \\
\hline I FUT go/ PREF.FUT I go & I FUT go & 'I shall go' \\
\hline b. I/Ị gà- àga & O máa lọ & \\
\hline You FUT go & You FUT go & 'You will go' \\
\hline $\begin{array}{l}\text { c. } \mathrm{O} \text { gà- àga } \\
\text { s/he FUT go }\end{array}$ & $\begin{array}{l}\text { Ó máa lọ } \\
\text { s/he FUT go }\end{array}$ & 'S/he will go' \\
\hline d. Ànyị gà- àga & A máa lọ & \\
\hline We FUT go & We FUT go & 'We shall go' \\
\hline e. Unù gà- àga & máa lọ & \\
\hline You FUT go & You FUT go & 'You will go’' \\
\hline f. Ha gà-àga/ Agà & Wọn máa lọ & \\
\hline They FUT go/PREF.FUT they go & They FUT go & 'They will go' \\
\hline
\end{tabular}

\subsection{Findings and Implications on Speakers of Igbo and Yoruba \\ Learning other's Language as well as their Teachers}

We discovered from the study that present and past forms of the verb are expressed in the same manner in Igbo and Yoruba. In 
Igbo, there is indicative suffix $-\mathrm{rV}$ which may be obligatorily deleted or optionally used with certain verbs in the present, and obligatorily used for verbs in the past, but in Yoruba, the present and past tense are unmarked.

It is noticed that for the formation of future tense in Igbo and Yoruba, the future morpheme follows the subject pronouns and precedes the prefixed verb root or the infinitive form of the verb. In Igbo, the hyphen - is written between the future morpheme and the verb, but in Yoruba, the future morpheme is written separately without a hyphen. Also, in Igbo the $1^{\text {st }}$ person singular pronoun and the $3^{\text {rd }}$ person plural pronoun can come after the future morpheme - ga which is prefixed with $a$ followed by the prefixed verbroot or the infinitive of the verb root, but in Yoruba all the subject pronouns come before the future morpheme.

The presence of indicative suffix $-r V$ which may be obligatorily deleted or optionally used with certain verbs in the present, and obligatorily used for verbs in the past in Igbo, while in Yoruba, the present and past tense are unmarked may constitute spelling problem for learners of both languages. Also, the hyphen written between the future morpheme and the verb in Igbo, but the future morpheme is written separately without a hyphen in Yoruba will constitute spelling problem for learners. Finally, the $1^{\text {st }}$ person singular pronoun and the $3^{\text {rd }}$ person plural pronoun which can come after the future morpheme $-g a$ prefixed with $a$ followed by the prefixed verbroot or the infinitive form of the verb root, while all the subject pronouns come before the future morpheme in Yoruba may constitute spelling problem.

To overcome these problems, there is the need for the students to put in extra effort to learn appropriately how to produce and write the unfamiliar differences in tense formation in both languages. The teachers, on their part, should first let the students 
be familiar with the areas of differences and correct them immediately as they misrepresent them. It is also very important for the teachers to avail themselves of the available materials on contrastive studies of the Igbo and Yoruba languages, like this study, to help them predict possible areas of difficulty for their students and prevent them from manifesting.

\section{Summary and Conclusion}

This paper has shown that there are differences in tense formation in the Igbo and Yoruba languages; while the indicative suffix $-r V$ which may be obligatorily deleted or optionally used with certain verbs in the present, and obligatorily used for verbs in the past in the former, the present and past tense are unmarked in the latter. Also, the hyphen - is written between the future morpheme and the verb in Igbo, but the future morpheme is written separately without a hyphen in Yoruba; the $1^{\text {st }}$ person singular pronoun and the $3^{\text {rd }}$ person plural pronoun can come after the future morpheme $-g a$ prefixed with $a$ followed by the prefixed verbroot in Igbo, while all the subject pronouns come before the future morpheme in Yoruba. This has implication for speakers of the two languages learning the other language as they are likely to commit spelling errors as well as their teachers.

The paper has made useful suggestions concerning how the teachers can help their students overcome the identified learning problems such as letting them be familiar with the areas of differences and correcting them immediately they misrepresent them as well as trying to prevent the errors from manifesting through reading appropriate contrastive studies on the Igbo and Yoruba languages. If the suggestions are implemented, with the students putting in conscious efforts to overcome their learning 
difficulties, they will be able to acquire full competence with ease and in record time.

\author{
Aghaegbuna Haroldson Uwaezuoke \\ Department of Linguistics \\ Nnamdi Azikiwe University, Awka \\ uwaezuokeha@gmail.com \\ ha.uwaezuoke@unizik.edu.ng \\ \&

\section{Olufunmilayo M. Ogunkeye} \\ Department of Languages and \\ Linguistics \\ University of Jos, Jos \\ fogunkeye@yahoo.com/ \\ olufunmilayo.ogunkeye@gmail.com
}

\title{
References
}

Afigbo, A. E. 1981. Ropes of sand (studies in Igbo history, and culture). Ibadan: University Press Limited.

Anagbogu, P. N. \& C. A. Eme. 2000. Teaching Nigerian adolescents the English language: Problems and implications for language pedagogy. Journal of Counselling. 1, 52 -63.

Anagbogu, P. N., B. M. Mbah \& C. A. Eme. 2010. Introduction to linguistics, 2nd edition. Awka: Amaka Dreams.

Aronoff, M. 2011. The gradual emergence of phonological form in a new language. $29.503-543$.

Bhat, Shankara D.N. 1999. The prominence of tense, aspect and mood. Philadelphia: John Benjamins. 
Comrie, B. 1985. Tense. Cambridge: Cambridge University Press.

Corder, P. S. 1973. Introducing applied linguistics. Britain: Hazel Watson.

Eme, C. A. \& S. I. Odinye. 2008. Phonology of standard Chinese and Igbo: Implications for Igbo students learning Chinese. Nkuzi Oтuтu Asusu (NKOA) Journal. 1, 26-37.

Eme, C. A. and H. A. Uwaezuoke. 2015. Phonology of Ụmụòlum Igbo and Standard Igbo: Implications for Teaching and Learning of Standard Igbo in Ụmụ̀òlum. Nkuzi na Omumu Asusu (NKOA) Journal

Emenanjo, E. N. 1978. Elements of modern Igbo grammar. A descriptive approach. Ibadan: Oxford University Press.

Emenanjo, E. N. 1985. Auxiliaries in Igbo syntax: A coparative study. Studies in African Grammatical Studies No 2. Indiana University Linguistics Club.

Emenanjo, E. N. 2015. A grammar of contemporary Igbo: Constituents, features and processes. Port Harcourt: M \& J Grand Orbit Communication Ltd.

Enemor, A. O. and E. C. Osinomumu. 2005. Ntughe grama na mofoloji di elu. Onitsha: Next Generation Computer Press Limited.

Eyisi, Joy. 2004. A grammar of English - the student companion. Awka: Anthony Publishers.

Green, M. M. \& G. E. Igwe. 1963. A descriptive grammar of Igbo. Berlin: Akademia-Verlag.

Greenberg J. 1966. Languages of Africa. Mouton \& co., The Hague. Indiana University, Bloomington.

Hartmann, R. R. K. 1980. Contrastive textology: A comparative discourse analysis in applied linguistics. Julius Gros: Harlay Hieldelberg. 
James, C. 1983. Contrastive analysis. Great Britain: Longman Press.

Lado, R. 1957. Linguistics across culture: Applied linguistics for Nigerian teachers. An Arbors: University of Michigan

Lyon, J. 1968. Introduction to theoretical linguistics. England: Cambridge University Press.

Mensah, E. O. and O. N. Ojukwu. 2003. A contrastive analysis of English \& Efik central vowels: The pedagogical implications. In Ndimele ed. Four Decades in the Study of Languages and Linguistics in Nigeria: A Festschrift for Kay Williamson. 235 - 241. Port Harcourt: Emhai Printing and Publishing Co.

Nwankwo, Uju C. 2009. A contrastive study of English and Igbo prepositions. M.A. thesis. Department of Linguistics, Nnamdi Azikiwe University, Awka.

Obiamalu, Greg Orji. 2015. Functional categories in Igbo- A minimalist perspective. In O.M. Ndimele (ed). The Landmarks Series Publication. Series 4. Port-Harcourt: Grand Orbit Publication.

Odunuga, S. 1982. Tense and aspect in Yoruba. In Adebisi Afolayan. Ed. Yoruba language and literature. Ife: University Press Ltd and University of Ife Press.

Ogunbowale, P. O. 1970. The essentials of Yoruba language. London: University of London Press.

Ogunkẹyẹ, O. M. 2003.“The Yorùbá Serial Verb Constructions”. CONTEXT : Journal of Social \&Cultural Studies Vol. 6 N0 2 pp 1-14.

Ogunkẹye, O. M. 2004."On the Lexical Status of Verb-Verb and Verb-Noun compounds in Yorùbá". Maiduguri Journal of Linguistic and Literary Studies (MAJOLLS) Volume V1 
pp 1-13.

Okonkwo, M. N. 1974. A complete course in Igbo grammar. Lagos: Macmillan Nigerian Publishers.

Okorji, R.I. and C.O. Okeke. 2009. The effects of the differences between the sound systems of English and Igbo on the effective learning of English in Nigerian schools. Nkuzi na Oтumu Asusu (NKOA), vol. 2, 25-36.

Oluikpe, B.O. 1978. English in Igboland. Onitsha: Africana.

Omamor, Augusta P. 1982. Tense and Aspect in Itsekiri. Journal of West African Languages 12, 95-129.

Palmers, F.R. 1987. The English verb. London: Longman Linguistic Library.

Saeed, J. I. 2003. Semantics. U.S.A.: Blackwell Publishing Limited.

Uwalaka, Mary-Angela. 1988. The Igbo verbs: A semanticsyntactic analysis. Beitrage zur Africanistik (Wien), Band 35, Nr. 48.

Ward, Ida. 1935. A linguistic tour in Southern Nigeria. Africa. 8:1.

Welmers, B. F. and W. E. Welmers. 1968. Igbo: A learner's manual. Los Angeles: UCLA Press. 